\title{
Vocabulaire Technique International de l'Ingénieur
}

\author{
The Engineer's Technical and International Vocabulary
}

AYr IE COXcours DE M. G. RANSFORD ET DU PROFESSEUR GIROUD

\begin{abstract}
Dire qu'il n'est pas de vocabulare qui echappe aux lois générales de la linguistique peut paraitre un truisme. En fail, les vocabulatres techniques sont souvent mal équilibrés: on $y$ donne volontiers la phus grande place aux substanlifs; ce a quoi condaisent fatalement le dessin on le croquis, dont chaque partic appelle un équivalent, évidemment un nom.

Il n'en reste pas moins que le verbe, vocable par excellence de laction, ne sabrait elre négligé, mène lorsque son sens ne se limile pas strictement a la technique. C'est sur lai que se font les contresens les plus graves, et un yrand nombre d'approximations dangereases, ou simplement ridicules.

C'est donc une innovation toute all crédit de M. Ransford d'avoir consacré une étade entière anx verbes exprimant les maltiples nuances de l'idée de « couler $\gg$ - dont il est inutile de souligner l'imporfance en hydratique.
\end{abstract}

$$
\text { A. Gimovo. }
$$

\section{MOUILLER, COULER, DEVERSER ( $\left.{ }^{*}\right)$ (Suite)}

\section{VI. - Verres employés}

POUR L'EAC QUE L'ON PUISE OU QUI S'ECHAPPE.

To dip est un verbe très courant. Dans le domaine qui nous intéresse il signifie puiser un liquide avec un ustensile à écoper; il est souvent suivi de «out» ou « up ». Par exemple : puiser de l'ean chande dans la bouillote de la cuisinière (to dip water up from a boiler).

To lade exprime l'action de remplir ou de vider un récipient avec l'aide d'un pochon, d'un puisoir (d'un pucheux) ou de ruelque chose d'analogue; par exemple: on vide (to lade out) un cuveau avec un pochon. To ladle esl spécifiquement prendre avec une louche (la soupe). To bale ou to bail est un synonyme de to lade, mais s'emploie spécialement quand il sagit de retirer à la main l'eau d'une enbarcation (écoper).

\begin{abstract}
There is no vocabulary that can alsregard the basic laws of language. However obvious this statement may appear, it is a fact that in technical vocabularies, undue importance is often given to nouns, at the expense of verbs; this is particularly the case when they are made from drawings, the name of each part of the drawing being translated into one or several other languages.

Now the importance of verbs-even when not strictly technical-cannot be overlooked. They eipress actions, and are liable to many misinterpretations, some of them merely ludicrous, others leading to serious mistakes in meaning. II is therefore highly original of Mr. Ransford to have devoted a full study to the verbs expressing the various shades of meaning of to flow" - a word, needless to say, of paramonnt importance in hydraulics.
\end{abstract}

A. Giroun.

\section{WET; FLOW, POUR( $\left.{ }^{\star}\right)$ (Continued)}

\section{YI. - VERBS USED FOR THE ESCAPE OR REMOVAL OF LIQUID}

To dip is a commonly employed verb. In the present connection it means to take liquid out of a container with a utensil which scoops up, often with out or up added; as, to dip water up from a boiler.

To lade, as to lade water out of a tub, is to lift in or out with a ladle, dipper or the like; to ladle is specifically to dip up with a ladle (as, to ladle soop). To bale or, as it is also spelt, to bail means to lade; it is particularly used for lading water out of a boat by hand.

* La Howille Blanche, $n^{\circ} 4-1952$, p. 626; n" 5-1952, p $732 ; n^{\circ} 1-1953, p .79$. 


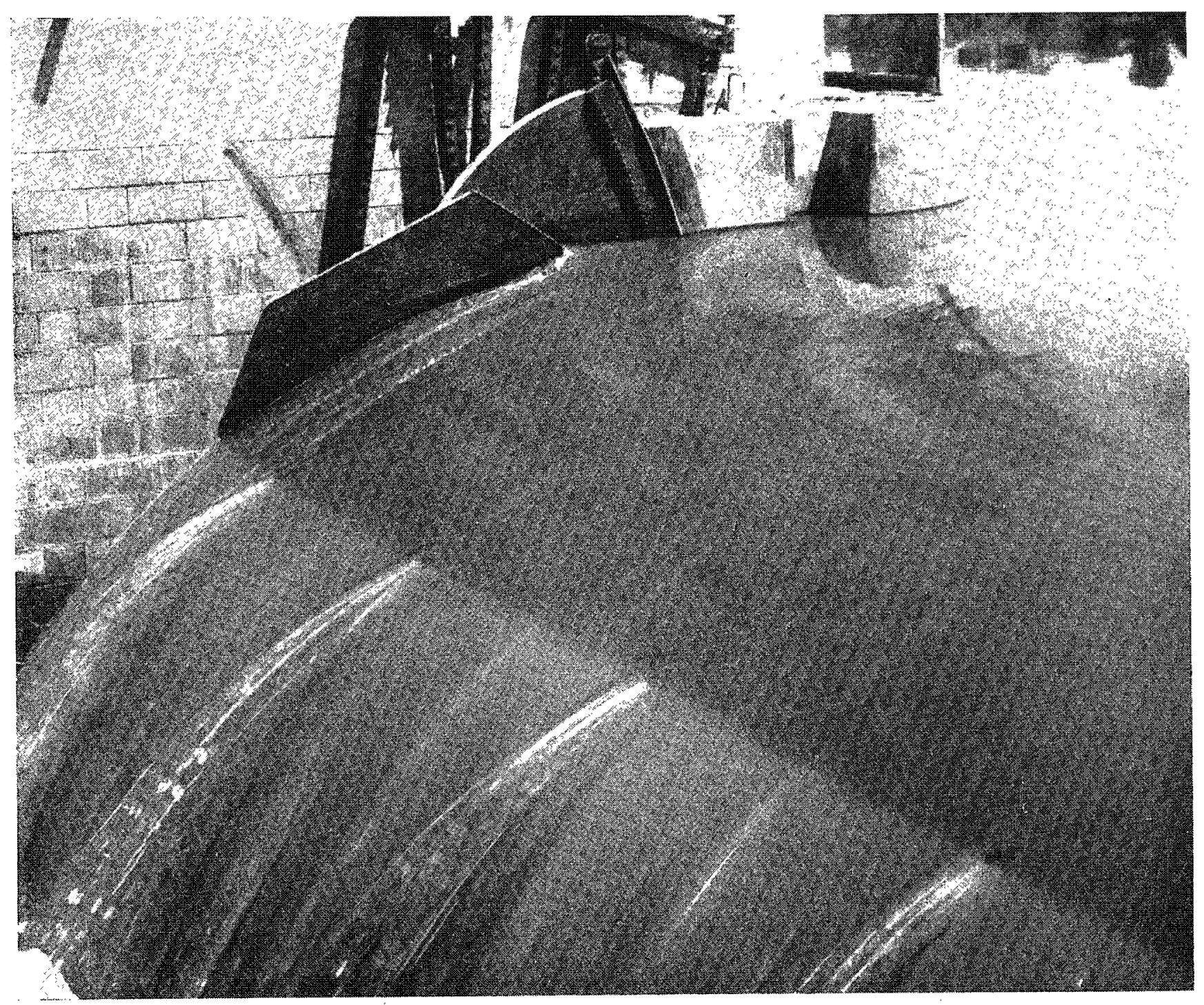

Profil de nappe dérersante. Drandown curve.

To scoop (pniser) est un terme plus général que to lade. Il est couramment employé dans le sens de prélever avec une pelle, une cuiller (un « couloir » d'épicier), de la farine, de la terre aussi bien qu'un liquide. Une locomotive à rapeur puise de l'eau, en marche, (scoops up et non lades ou bales) dans une fosse disposée entre les rails.

To dish est parlois employe, improprement, dans le sens de to lade.

To spoon signifie prendre da la cuiller.

To decant est vider un récipient tris lentement afin de ne pas agiter le dépôt qui se trouve au fond. Ce rerbe peut également signifier transvaser.
To scoop is a somewhat more general term than to lade, inasmuch as it is currently used for the removal (by a scoop) of flour, soil and so on, as well as for the removal of liquids, from a container. It often connotes speedy and forcible removal of liquid; a steam locomotive in motion scoops up (but does not lade or bale) water from watering troughs laid between the rails.

To dish is somelimes, bul improperly, used like to lade.

To spoon is used in the sense of to remove with a spoon.

To decant is to pour off from the edge of a vessel-or to pour off gently, as liquor, so as not to disturb the sediment or precipitalealso to pour from one vessel to another. 
To draw, dans l'une de ses nombreuses acceptions, peut vouloir dire tirer ou laisser échapper un liquide d'un récipient; par exemple : on tire l'eau d'un puits (to draw water from...). Drawdown peut désigner la hauteur dont s'abaisse le niveau d'cau dans un puits, par exemple, apress pompage - ou encore le profil tombant de la nappe d'eau au roisinage d'un déversoir (drawdown curve). Ce terme indique plus couramment le volume prélevé sur un stock quelconque (d'eau, d'énergie b́lectrique, etc.); en français : sontirage. Draw dock désigne un renfoncement de la berge d'une rivière aménagé en ćcluse. Drawbridge désigne un pont mobile de n'importe quel type (pont tournant, pont a bascule, pont roulant). Draw well est un puits d'où l'on tire l'eau à l'aide d'un seau et d'une corde.

To skim (écumer, écrémer) signifie enlever une pellicule à la surface d'un liquide avee une cuillere ou un instrument analogue.

\section{To pump correspond à pomper.}

To drain a sa place ici comme signifiant vider completement un récipient du liquide qu'il conlient; par exemple: on vidange (drain) un réservoir. Parfois to drain évoque un liquide s'écoulant petit à petit; par exemple l'eau passe, filte (drains), lentement à travers un sable fin. To drain est alors l'équivalent de to percolate.

On appelle drainage (drainage) l'assichement des terres par l'élimination de l'eau ou l'ensembe des lravaux entrepris dans ce but; spécifiquement c'est provoquer l'écoulement des eaux en excès sur un terrain par des conduits disposés en surface ou enterrés. Dans le herringbone system le collectent (main drain) et les drains (lateral drains) sont disposés en arétes de poisson. Dans le gridiron drainage deux collecteurs, faisant un angle entre eux, sont alimentés, chacun d'un seul coté, par des drains parallèles. Le système par drainage d'arrét (cutoff drainage) est destine a drainer des versants montagneux humides: des drains de poterie sont disposés sur la pente de facon à intercepter les eaux et à les empecher d'atteindre les terrains situés en contrebas. Dans le sinkhole drainage, l'eau est dirigée vers un puits drainant (drain well), creuse jusqu'à alteindre une assise perméable. Drain grate désigne une grille telle qu'on en place devant une bouche d'égout destinée à recueillir les eaux de ruissellement de la rue; elle sert à relenir les débris qui obstrueraient l'égout. Drain rocket est une sorte de feu de Bengale émetlant une fumée abondante, souvent malodorante, signalant l'existence d'une fuite dans un igout.

Catch drain est le collecteur creusé au flanc d'une colline pour recueillir les eaux de ruissel-
To draw, in one of its many senses, means to lake out or to let out liquid from a receptacle; as, to draw water from a well. A drawdown may be the height by which the liquid surface level, as in a well, is lowered by pumping or alternatively, the curving downward of the water surface near an overfall weir (often, drawdown curve). In more extended usage, the term may also mean the quantity of water (or of electric power, etc.) which is removed from a reservoir by a decrease in level. A draw dock is a recess in a river bank serving as a lock. A drawbridge is a moving bridge of any variety (swing, hascule, lift, or roller). A draw well is a well from which water is drawn by bucket and rope.

To skim is to remove a film from the surface of a liquid, by means of a spoon or the like.

To pump is to cause the flow of a fluid by means of a pump; one pumps water from a well and into a reservoir.

To drain is here included as meaning to exhaust of liquid contents by draining them off; as, to drain a tank. Otherwise it means to flow off gradually; water drains slowly through fine sand. In this usage, it is equivalent to to percolate.

Drainage is the drawing of liquid or the provision of means for drawing it off; specifically, it is the removal of excess waler from land by means of surface or subsurface conduits. In herringbone drainage the main drain and the lateral drains have a herringhone arrangement. In gridiron drainage two mains at an angle to each other are fed by parallel laterals discharging into each main from a single side. In cutoff drainage, for draining seepy hillsides, tile drains are placed along the hillside to intercept the seepage and to prevent its reaching the land beneath. In sinkhole drainage, the water is drained through an absorbing well (drain well), sunk to a permeable stratum. A drain grate is a grate set at the entrance to a sewer where a street drain discharges into it, to trap material which would not readily pass along the sewer. A drain rocket is a kind of firework emitting much smoke and, often, stench which is used to detect leaks in drains.

A catch drain is a ditch along the side of a hill to catch the surface water; also, a ditch at the 
lement; c'est aussi parfois le fossé creusé le long d'un canal et destiné à évacuer le débit en excès. A la campayne ce sont généralement des drains en poterie disposés les uns à la suite des autres, sans joints, dans des tranchées qui sont ensuite comblèes.

To leak (fuir) signifie laisser involontairement un liquide s'échapper par un orifice ou une fente; un gaz fuit (leaks) par un trou, l'eau passe (leaks) cutre les hausses d'un barrage. To leak implique une certaine lenteur, alors que, au contraire, to run out suggère un phénomène rapide. A la place de ces deux verbes on pent employcr simplement to escape, bien qu'il soit plus couramment utilisé dans d'autres sens.

To sluice signifie faire passer l'eau dans un chenal, laver à grando eau, débourber, excaver grâce à un jet d'eau (on l'a déjà vu précédemment) ${ }^{*}$, ou enfin faire passer, dans un chenal, par exemple du bois.

Sluice gate est une vanne à glissement.

To pipe veut dire: transporter par tuyaux; to siphon: tirer, vidanger par siphonnage (siphonner).

To put, c'est s'écouler dans ou hors de, quand il s'agit d'un cours d'eau. On peut dire qu'une rivière puts (se jefte) dans un lac. On l'employait autiefois pour la sève.

To disembogue veut dire passer de l'embouchure d'un fleuve à la mer; se déverser telle une rivière se jetant daus la mer ou dans un lac (déloucher!.

To vent exprime l'idée d'une décharge à travers un trou. A vent est une petite ouverture tel le trou de fausset d'un tonneau.

\section{(A suive).}

side of a canal to catch surplus water. An agricultural drain is a drain consisting of lengths of earthenware pipe laid with open joints in ditches which are then backfilled.

To leak is to let fluid in or out, contrary to intention, through a hole or crevice; gas lealis through a hole, water past flashboards.

A somewhat slow motion is implied by to leak; to run out, on the other hand, suggests rapidity of escape. In place of either word one can simply use to escape, though this is more common in olher senses.

To sluice is to draw off through a sluiceway, to wash or scour, or (as already noted) * to remove by using a stream of water, or finally, to transport in a sluiceway, as logs. A sluice gate is the sliding gate of a sluice. To pipe is to convey by a pipe; to siphon, to draw off by a siphon.

To put is to flow in or out of - said of a stream - as a river puts into a lake, also formerly of sap.

To disembogue, to pass through the mouth of a stream into a sea, to flow into; to pour out as a stream, to discharge into an ocean, a lake, as waters.

To vent, to issue forth by, or as by, a vent; to go, flow, pour away through a vent (a vent: a small aperture, a hole, as a vent in a cask).

(To be continued).

\footnotetext{
* La Houille Blanche, $\mathrm{n}^{\circ} 5,1952$, p. 735.
} 